\title{
Tannhirðuvenjur unglinga á Íslandi í 10. bekk árin 2014 og 2016
}
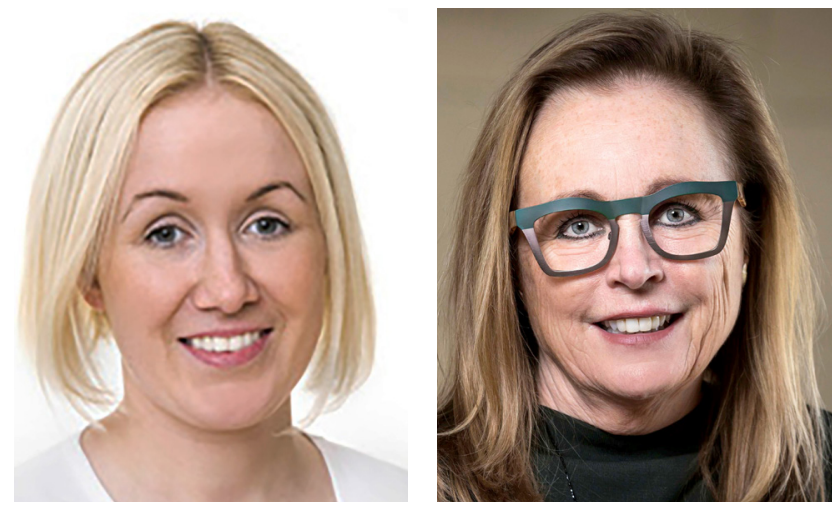

\author{
DANA RÚN HEIMISDÓTTIR, CAND. ODONT, MS \\ INGA B. ÁRNADÓTTIR DOKTOR. ODONT PRÓFESSOR, TANNLÆEKNADEILD HÁSKÓLA ÍSLANDS
}

NETFANG: DANAHEIMIS@GMAIL.COM TANNLAEKNABLAĐIĐ 2019; 37: 46-51

doi: 10.33112/tann.37.1.5

\section{ÁGRIP}

Inngangur: Markmið rannsóknarinnar var að kanna venjur unglinga i 10 bekk á Íslandi árin 2014 og 2016 við munnhirðu svo sem tíðni tannburstunar, notkun á tannpræði og flúormunnskoli. Kannað var hvort börnin fari reglulega í skoðun til tannlæknis, hvort pau pekki og viti að pau falli undir samning á milli Sjúkratrygginga Íslands og Tannlæknafélags Íslands um gjaldfrjálsar tannlækningar barna. Með pessu er hægt að gera fræðslu markvissari og efla forvarnir.

Efniviður og aðferðir: Megindlegri rannsóknaraðferð var beitt par sem prentaðir spurningalistar voru lagðir fyrir unglinga í 10 bekk árin 2014 og 2016. Við úrvinnslu gagna var notað tölfræðiforritið R og Rstudio. Skýribreytur voru búseta, kyn og upprunaland foreldra. Lýsandi tölfræði var notuð fyrir niðurstöður rannsóknarinnar.

Niðurstöður: Svörun var alls 49\% ( $n=4116)$, nokkuð jöfn eftir kynjum, 51 \% ( $n=2092)$ strákar og 49\% ( $n=2023)$ stelpur. Flestir voru búsettir á höfuðborgarsvæði og nágrenni (67\%), 30\% til sjávar og 3\% bjuggu til sveita. 86\% ( $n=3521)$ áttu foreldra af íslenskum uppruna en 14\% ( $n=593$ ) foreldri eða foreldra af erlendum uppruna. 76,6\% ( $n=446)$ unglinga með foreldra að erlendum uppruna leita tannlæknabjónustu reglulega samanborið við 91,3\% (n=3185) unglinga með íslenska foreldra. Árið 2013 var gerður samningur um greiðslupátttöku ríkis vegna tannlæknapjónustu barna að 18 ára aldri sem tók gildi í áföngum fram til 2018. 88,2\% ( $n=2021$ ) fóru reglulega til tannlæknis árið 2014 en 90,3\% (n=1626) árið 2016. Strákar bursta sjaldnar en stelpur, nota síður tannpráð og flúormunnskol og pví með marktækt lakari munnhirðu en stelpur.

Umræða: Rannsóknin nær yfir allt landið og veitir góða innsýn í munnhirðu 15 ára unglinga á Íslandi. Ekki er marktækur munur á milli landshluta sem gefur til kynna að landið sé orðið einsleitara eins og fyrri rannsóknir hafa sýnt fram á. Niðurstöðurnar benda til að strákar hafi almennt lakari munnhirðu en stelpur og parf mögulega að sníða forvarnir betur að peim.

Lykilorð: Munnhirða, tannburstun, tannpráður, forvarnir 


\section{Inngangur}

Unglingsárin er sá aldur par sem einstaklingar öðlast aukið sjálfstæði, ábyrgð og oft á tíðum fjárræði. 15 ára unglingar bera ábyrgð á munnhirðu, stjórna neysluvenjum sínum að miklu leyti og pví mikilvægt að beina forvörnum að peim. Síðasta rannsókn sem gerð var á munnheilsu barna á Íslandi, MUNNís rannsóknin, var gerð árið 2005 (1,2) og pví liggja engar áreiðanlegar upplýsingar fyrir um tannheilsu barna á Íslandi í dag. Tannheilsa peirra hefur reynst verri en hjá jafnöldrum á Norðuröndum par sem tannlæknapjónusta barna er greidd að fullu af hinu opinbera (3,4). 15. maí 2013 tók gildi samningur á milli Sjúkratrygginga Íslands (Sí) og Tannlæknafélags Íslands (TFí) um gjaldfrjálsar tannlækningar barna. Samkvæmt samningnum eru tannlækningar barna greiddar að fullu af sí fyrir utan árlegt 2.500 kr. komugjald. Samningurinn tók gildi í áföngum en frá 1. janúar 2018 voru öll börn komin með fulla greiðslupátttöku (5). Með pessum samningi má ætla að tannheilsa íslenskra barna fari batnandi, pótt engar rannsóknir styðji pað.

Frá árinu 1983 stóð Tannverndarráð fyrir árlegum Tannverndardegi en árið 2003 var deginum breytt í heila viku. Markmið tannverndarviku er að vekja athygli á mikilvægi góðrar tannheilsu með fræðslu um varnir gegn tannskemmdum (6). Frá árinu 2005 hefur Embætti landlæknis staðið fyrir tannverndarvikunni og er nýtt pema á hverju ári.

Forvarnir og heilsuefling er námskeið sem kennt er á fyrsta ári í tannlæknisfræði (7). Par fer fram umræða milli nemenda og kennara hvernig gera má forvarnarfræðslu áhugaverðari fyrir unglinga. Farið er í grunnskóla, nemendur i 10. bekk spurðir og gerð parfagreining. Nefndu pau m.a að ef Justin Bieber sæi um fræðsluna myndu pau taka meira mark á henni. Parna kviknaði hugmynd og fyrir tannverndarviku 2014 fékk TFí í samstarfi við Tannlæknadeild Háskóla Ísland (THÍ) styrk úr Lýðheilsusjóði til pess að búa til fræðslumyndband par sem Jón Jónsson tónlistamaður fjallaði um tannheilsu. Að pessu stóðu Inga B. Árnadóttir prófessor, Kristín Heimisdóttir páverandi formaður TFí og Anný Antonsdóttir framkvæmdastjóri TFí. Tannlæknar og tannlæknanemar fóru i flesta skóla á höfuðborgarsvæðinu og tannlæknar út á landi voru með fræðslu og dreifðu spurningalistum til nemenda.

Í sænskri rannsókn voru 15 ára börn skoðuð og í ljós kom að börn sem áttu foreldra af erlendum uppruna voru með fleiri byrjandi úrkalkanir í glerungi en börnum sænskra foreldra. Börn foreldra af erlendum uppruna en fædd í Svípjóð eða fluttust til Svípjóðar fyrir eins árs aldur voru jafn líkleg og börn af sænskum uppruna að vera með tannskemmdir, en aðflutt börn til Svípjóðar eftir 7 ára aldur voru tvisvar til prisvar sinnum líklegri að vera með tannskemmdir (8). I lannarri sænskri rannsókn kemur fram að unglingar sem eru innflytjendur eða eiga foreldra sem eru innflytjendur höfðu minni pekkingu á munnsjúkdómum og munnheilsu en unglingar sænskra foreldra. Hinsvegar sögðu unglingar með annan en sænskan uppruna oftar að tennur væru peim mikilvægar miðað við sænska unglinga. Í danskri rannsókn kemur fram að unglingar sem eiga erlenda foreldra eru líklegri til pess að bursta sjaldnar en tvisvar á dag miðað við unglinga sem eiga danska foreldra (9). Engar íslenskar rannsóknir á pessu sviði eru til hér en líklegt að staðan sé svipuð og á hinum Norðurlöndum. Ofangreindar niðurstöður gefa til kynna nauðsyn pessað beina fræðslu sérstaklega að pessum börnum ásamt foreldrum sem í mörgum tilvikum hafa ekki hlotið mikla tannfræðslu.

\section{Efni og aðferðir}

Notuð var megindleg rannsóknaraðferð og spurningalisti lagður fyrir nemendur i 10 bekk á Íslandi i Tannverndarviku árin 2014 og 2016. Búseta var flokkuð eftir staðsetningu grunnskóla á 1. höfuðborgarsvæði, 2. til sjávar eða 3. til sveita, líkt og Sigfús pór Elíasson prófessor og MUNNís rannsóknin flokkaði byggðarlög í fyrri rannsóknum $(10,11,12)$. Spurningalistinn samanstóð af átta spurningum, aðallega krossaspurningum. Fyrstu tvær vörðuðu bakgrunn pátttakenda, kyn og upprunaland foreldra. Næstu prjár spurningar sneru að tannhirðu p.e hversu oft á dag pau bursti tennur, hvort pau noti tannpráð eða flúor munnskol. Í spurningu 7 var spurt hvort pau fari reglulega til tannlæknis að eigin mati og í spurningu 8 hvort pau viti hvað kosti að fara til tannlæknis. Tölfræðiúrvinnsla var unnin með tölfræðihugbúnaðinum R (The R Foundation for Statistical Computing, Vienna, Austria), (R-3.3.2) og Rstudio (Rstudio, Boston, USA). Niðurstöðum var lýst með tíðni, meðaltölum og hlutföllum. Munur á meðaltölum og hlutföllum var prófaður með t-prófum og kíkvaðrat-prófum. P - gildi lægri en 0,05 voru talin tölfræðilega marktæk. Einungis var unnið með ópersónugreinanleg gögn og rannsóknin var sampykkt af Rannsóknarnámsnefnd lækna-og tannlæknadeildar Háskóla Î́lands auk Vísindasiðanefndar (VSN-16-138).

\section{Niðurstöður}

Samkvæmt upplýsingum frá Hagstofu Ísland um fjölda 15 ára unglinga árin 2014 og 2016 var svahlutfall 48.9\% (Tafla1). Bakgrunnsbreytur spurningalistans voru kyn, búseta og upprunaland foreldra (Tafla 2). Spurningalistar frá báđum árum voru lagðir saman og unnið úr niðurstöðum samkvæmt pví, nema annað sé tekið fram í texta. 


\begin{tabular}{|l|c|c|c|}
\hline & $\mathbf{2 0 1 4}(\mathbf{n})$ & $\mathbf{2 0 1 6}(\mathbf{n})$ & Alls (n) \\
\hline Unglingar í 10. bekk & 4264 & 4181 & 8445 \\
\hline Svaraðir spurningalistar & 2307 & 1828 & 4135 \\
\hline Svarhlutfall (\%) & 54,1 & 43,7 & 48,9 \\
\hline
\end{tabular}

Tafla 1. Svörun miðað við fjölda unglinga i 10. bekk árin 2014 og 2016.

\begin{tabular}{|l|c|c|c|}
\hline & $\mathbf{2 0 1 4}(\mathbf{n})$ & $\mathbf{2 0 1 6}(\mathbf{n})$ & Alls (n) \\
\hline Kyn & & & \\
\hline Stelpur & 1121 & 902 & 2023 \\
\hline Strákar & 1172 & 920 & 2092 \\
\hline Búseta & & & \\
\hline Höfuðborgarsvæði og nágr. & 1415 & 1344 & 2759 \\
\hline Til sjávar & 831 & 407 & 1238 \\
\hline Til sveita & 61 & 77 & 138 \\
\hline Uppruni foreldra & & & \\
\hline Íslenskir foreldrar & 1963 & 1558 & 3521 \\
\hline Erlendir foreldrar & 336 & 257 & 593 \\
\hline
\end{tabular}

Tafla 2. Fjöldi svara eftir kyni, búsetu og uppruna foreldra árin 2014 og 2016.

Af svöruðum spurningalistum voru 51\% $(n=2092)$ strákar og 49\% ( $n=2023)$ stelpur. 67\% ( $n=2759)$ voru búsett á höfuðborgarsvæðinu og nágrenni, 30\% ( $n=1238)$ til sjávar og 3\% ( $n=138)$ til sveita. $85 \%$ áttu foreldra af íslenskum uppruna árið 2014 og 86\% árið 2016.

Tannhirðu pátttakenda má sjá í Töflu 3.

\begin{tabular}{|l|c|c|c|}
\hline & $\mathbf{2 0 1 4}(\mathbf{n})$ & $\mathbf{2 0 1 6}(\mathbf{n})$ & Alls (n) \\
\hline Tídni tannburstunar & & & \\
\hline Tvisvar á dag eða oftar & 1820 & 1402 & 3222 \\
\hline Einu sinni á dag & 424 & 361 & 785 \\
\hline Sjaldnar & 57 & 57 & 114 \\
\hline Notar pú tannprád? & & & \\
\hline Já, daglega & 229 & 155 & 384 \\
\hline Já, nokkrum sinnum í viku & 1025 & 756 & 1781 \\
\hline Nei & 1041 & 905 & 1946 \\
\hline Notar pú flúormunnskol? & & & \\
\hline Já & 1057 & 712 & 1769 \\
\hline Nei & 1224 & 1079 & 2303 \\
\hline
\end{tabular}

Tafla 3. Tannhirða pátttakenda (tiðni) árin 2014 og 2016.

Á Mynd 1 sést tíðni tannburstunar eftir kyni. Stelpur bursta marktækt oftar en strákar $(p<0,001)$.

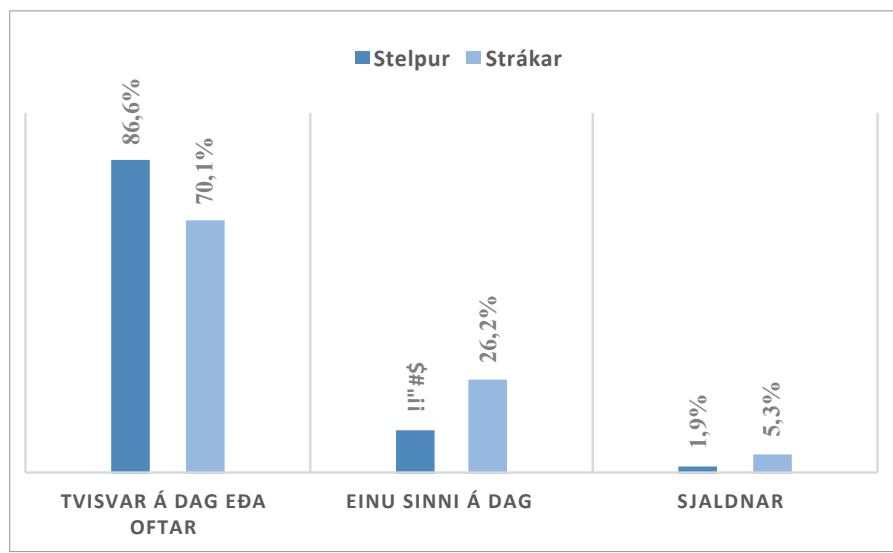

Mynd 1. Tiðni (\%) tannburstunar eftir kyni $(n=4101)$

Mynd 2 sýnir tíðni tannburstunar eftir búsetu. Peir sem búa í dreifbýli eru líklegri til pess að bursta sjaldnar $(p<0,009)$. Ekki var marktækur munur á svörun eftir uppruna foreldra $(p<0,195)$.

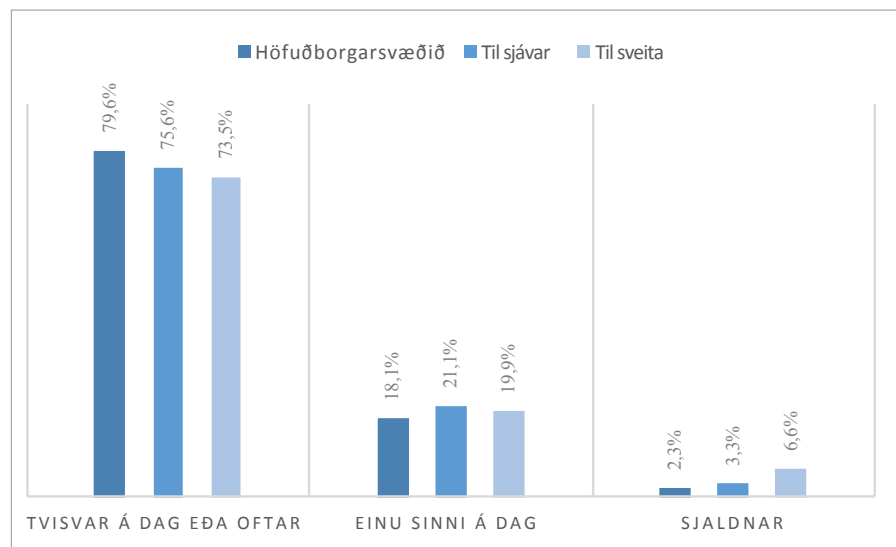

Mynd 2. Tiðni tannburstunar eftir búsetu $(n=4121)$

Stelpur nota marktækt oftar tannprád en strákar $(p<0,001)$ en ekki er marktækur munur á notkun tannpráđs eftir búsetu $(p<0,096)$, né eftir uppruna foreldra $(p<0,924)$.

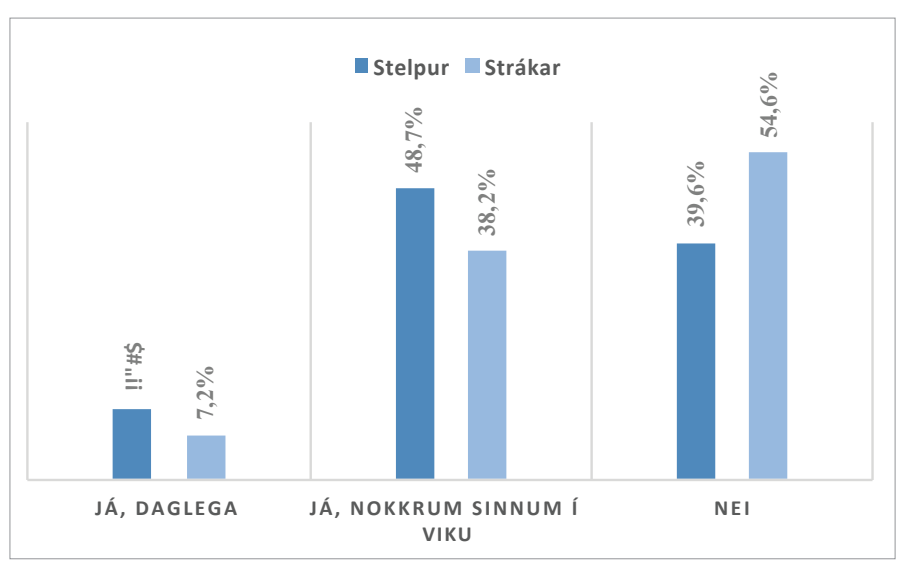

Mynd 3. Notkun tannpráđs (\%) eftir kyni $(n=4111)$ 
46\% ( $\mathrm{n=918)} \mathrm{stelpna} \mathrm{nota} \mathrm{flúormunnskol,} \mathrm{en} \mathrm{41,1 \%}$ ( $n=846)$ stráka. Marktækur munur er par á ( $p<0,0018)$, en ekki á svörun eftir búsetu $(n=0,417)$. Börn sem eiga foreldra af erlendum uppruna nota marktækt oftar flúormunnskol $(\mathrm{p}<0,001)$.

$90,3 \%(n=1626)$ sögðust fara reglulega til tannlæknis árið 2016 miðað við 88,2\% (n=2021) árið 2014. Martækt fleiri fóru til tannlæknis árið 2016 en árið 2014 (p<0,035). pegar listar frá báðum árum eru skoðaðir segjast 91,9\% ( $n=1847$ ) stelpna fara reglulega til tannlæknis og $86,7 \%$ $(n=1787)$ stráka og er munurinn marktækur $(p<0,001)$. pátttakendur til sveita fara marktækt sjaldnar í reglubundnar skoðanir til tannlæknis bæði árin $(p<0,001)$. Einnig er marktækur munur eftir uppruna foreldra, 76,6\% ( $n=446)$ unglinga sem eiga foreldri/foreldra af erlendum uppruna fara reglulega til tannlæknis en 91,3\% ( $n=3185)$ sem eiga íslenska foreldra $(p<0,001)$ (Mynd 4).

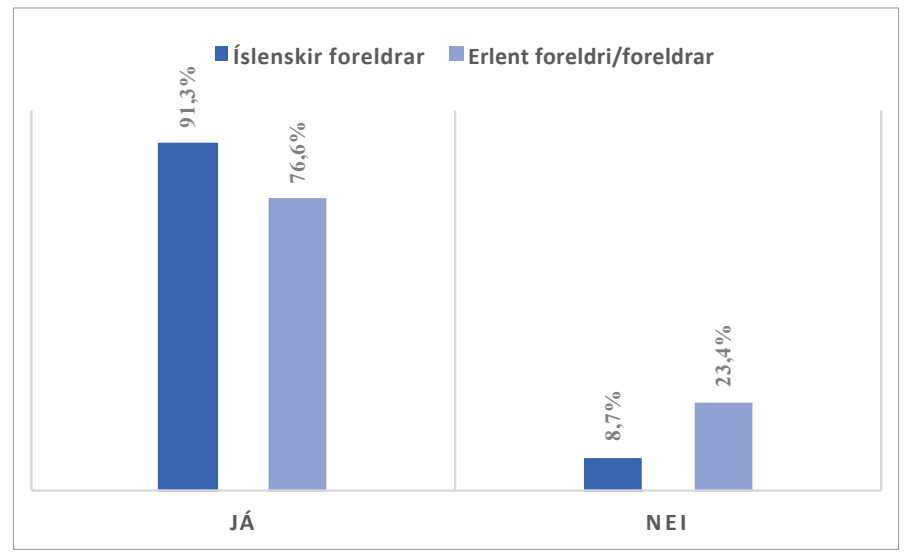

Mynd 4 Reglubundin skoðun hjá tannlækni eftir uppruna foreldra $(n=4071)$

$37,1 \%$ ( $n=1527)$ unglinganna veit að pað kostar 2.500 $\mathrm{kr}$ að fara til tannlæknis. Marktækt fleiri stelpur 39,7\% ( $n=798)$ svara rétt, en $34,7 \%(n=724)$ stráka $(p<0,001)$. Aðeins $27,5 \%$ ( $n=38)$ sem búa til sveita svara spurningunni rétt en 36,6\% ( $n=451)$ til sjávar og 37,8\% ( $n=1038)$ á höfuðborgarsvæði. Marktækt fleiri sem eiga íslenska foreldra svöruðu rétt $(p<0,001)$.

\section{Umræða}

Almennt fara unglingar reglulega til tannlæknis, en peir sem eiga foreldra af erlendum uppruna fara sjaldnar. Skipting milli landsvæða var ójöfn par sem töluvert færri voru búsettir til sveita og pví parf að taka niðurstöður um marktækni með fyrirvara. Munnhirðan var verri hjá strákum en stelpum, peir bursta sjaldnar tennur, nota sjaldnar tannpráð og flúormunnskol. Álíka mynstur er einnig að finna í erlendum rannsóknum $(13,14)$. petta er umhugsunarvert og nauðsynlegt að beina forvörnum betur að strákum og gera pá meðvitaðri um eigin munnheilsu. prátt fyrir að búið sé að bæta tannheilsu barna á síðastu áratugum á Vesturlöndum er tannáta enn einn algengasti sjúkómur sem hrjáir börn á heimsvísu og virðist fara vaxandi (15). Ef niðurstöður úr pessari rannsókn eru bornar saman við könnun á vegum tannheilsudeilar HTR árið 2002 par sem 750 börn í 7 - 10 bekk svöruðu spurningalista um munnhirðuvenjur sögðust 73\% barnanna bursta tvisvar á dag eða oftar (16) en 78\% í pessari rannsókn. Fram kom að 7\% notuðu tannpráð alltaf en 19\% aldrei. Í pessari rannsókn kemur fram að 9\% nota tannpráð daglega og $47 \%$ aldrei.

Jákvætt er að aukning sé á reglulegum tannlæknaheimsóknum milli áranna 2014 og 2016 og ætla má að samningur Sí og TFí um gjaldfrjálsar tannlækningar barna hafi par áhrif. Peir sem eru búsettir til sveita segjast fara sjaldnar reglulega til tannlæknis og er pað umhugsunarvert. Mögulega stafar pað af verra aðgengi að tannlæknum. pað er hinsvegar áhyggjuefni að peir sem eiga foreldra af erlendum uppruna fara síður reglulega til tannlæknis eða 76,6\% miðað við 91,3\% sem eiga foreldra af íslenskum uppruna. Mögulega parf að kynna samning um gjaldfrjálsar tannlækningar barna betur fyrir pessum hópi. Samkvæmt tölum frá Sí voru 383415 ára börn eða á 15 aldursári með skráðan heimilistannlækni árið 2014 sem er 90\% barna. Samsvarandi hlutfall 2016 var 99\% sem hlýtur að teljast virkilega gott.

\section{Ályktun}

Bæta má forvarvarnir fyrir ákveðna hópa t.d barna af erlendum uppruna ef ná á settum markmiðum um lækkun tannátutíðni og glerungseyðingu. Skoða má hvort forvarnafræðsla, eins og hún er í dag, henti frekar stelpum en strákum par sem peir hafa almennt lakari munnhirðu. Flestir segjast fara í reglulega til tannlæknis sem er staðfest í upplýsingum frá S.Í.. Langflestir eru með skráðan heimilistannlækni sem ætti að sjá um innköllun peirra í reglulegt eftirlit.

\section{Pakkir}

Pakkir til tannlækna og tannlæknanema sem tóku pátt í Tannverndarviku 2014 og 2016 og sáu um dreifingu spurningalista í skóla landsins. Sérstakar pakkir fær leiðbeinandinn minn, Inga B. Árnadóttir prófessor við 
THÍ fyrir frábært samstarf og góðan stuðning í meistaranáminu. Pakka sömuleiðis Sigurði Rúnari Sæmundssyni og Hólmfríði Guðmundsdóttur en pau skipuðu meistaranámsnefndina. Thor Aspelund og ađrir hjá tölfræðiráđgjöf Heilbrigðisvísindasviðs fá einnig bestu pakkir fyrir tölfræðiaðstoð.

\section{Heimildir}

1. Arnadottir IB, Holbrook WP, Eggertsson H, Gudmundsdottir H, Jonsson SH, Gudlaugsson JO, Saemundsson SR, Eliasson ST, Agustsdottir H. Prevalence of dental erosion in children: a national survey. Community Dent Oral Epidemiol. 2010;38(6):521-6.

2. Agustsdottir $\mathrm{H}$, Gudmundsdottir $\mathrm{H}$, Eggertsson $\mathrm{H}$, Jonsson $\mathrm{SH}$, Gudlaugsson JO, Saemundsson SR, Eliasson ST, Arnadottir IB, Holbrook WP. Caries prevalence of permanent teeth: a national survey of children in Iceland using ICDAS. Community Dent Oral Epidemiol. 2010;38(4):299-309.

3. Velferđarráđuneytið. Bætt heilbrigðispjónusta og heilbrigði ungs fólks á aldrinum 14-23 ára. Skýrsla starfshóps velferðarráðherra 2011 [cited 2017 11. mars]. Available from: http://www.landlaeknir.is/servlet/file/store93/item16227/Velferdbarna_04102011.pdf.

4. Widström E, Ekman A, Aandahl LS, Pedersen MM, Agustsdottir H, Eaton KA. Developments in oral health policy in the Nordic countries since 1990. Oral Health Prev Dent. 2005;3(4):225-35.

5. Sjúkratryggingar İslands. Gjaldfrjálsar tannlækningar barna [cited 2017 11. mars]. Available from: http://www.sjukra.is/heilbrigdisthjonusta/tannlaekningar/born-ogungmenni/tannlaekningar-barna-samkvaemt-samningi-si-og-tfi/.
6. Tannverndarrád. Tannheilsa.is. Tannverndardagur/vika. Available from: http://brunnur. stj.is/interpro/heilb/tannvernd.nsf/pages/wpp0101.

7. Háskóli İslands. TAN013G Forvarnir og heilsuefling 2016. Available from: https://ugla. hi.is/kennsluskra/index. php?tab=nam\&chapter=namskeid\&id=70214320180\&namskra $=0$.

8. Jacobsson B. WL, Johansson I. Dental caries and caries associated factors in Swedish 15 -year-olds in relation to immigrant background. Swed Dent J. 2005;29(2):71-9.

9. Bast LS, Nordahl H, Christensen LB, Holstein BE. Tooth brushing among 11- to 15-year-olds in Denmark: combined effect of social class and migration status. Community Dent. Health. 2015;32(1):51-5.

10. Ágústsdóttir $H$, Sæmundsson SR, Elíasson SP, Eggertsson H, Jónsson SH. Dreifing tannátu og glerungseyðingar eftir búsetu međal 1., 7. og 10. bekkinga á Íslandi: niðurstöđur úr MUNNÍS 2005. Tannlæknablaðið. 2009;27(1):23-8.

11. Eliasson $\mathrm{S}$, Richter $\mathrm{S}$. Lækkun á tî̃ni tannátu í barnatönnum hjá sex ára börnum á İslandi. Tannlæknablaðið. 2004;22:19-23.

12. Arnadóttir IB, Rozier RG, Sæmundsson SR, Sigurjóns H, Holbrook WP. Approximal caries and sugar consumption in Icelandic teenagers. Community Dent Oral Epidemiol 1998;26(2):115-21.

13. Clarkson BH. Introduction to cariology. Dent Clin North Am. 1999 Oct;43(4):569-78, v.

14. Stamm JW, Stewart PW, Bohannan HM, Disney JA, Graves RC, Abernathy JR. Risk Assessment for Oral Diseases. Adv Dent Res 1991;5(1):4-17.

15. Thylstrup A FO. Textbook of ClinicalCariology. 2nd ed. Copenhagen: Munksgaard; 1994.

16. Ágústsdóttir H, Ólafsdóttir JL. Könnun á vegum tannheilsudeildar HTR. Tannææknablaðið. 2002;20 (1):45-7. 
English Summary

\title{
Dental hygiene practices in Iceland for 10 grades in 2014 and 2016
}

\author{
DANA RÚN HEIMISDÓTTIR, DDS, MSC, UNIV. OF ICELAND, FACULTY OF ODONTOLOGY \\ INGA B. ÁRNADÓTTIR, DR. ODONT., PROFESSOR, UNIVERSITY. OF ICELAND, FACULTY OF ODONTOLOGY
}

ICELANDIC DENTAL JOURNAL 2019; 37: 46-51

doi: 10.33112/tann.37.1.5

Introduction. The aim of the study was to assess oral hygiene habits of 15-year old adolescents in Iceland in 2014 and 2016 such as the frequency of tooth brushing, use of dental floss and fluoride mouthwash. It was examined whether the children are regularly examined by the dentist, whether they know they are covered by an agreement between the Icelandic Health Insurance (IHI) and the Icelandic Dental Association for free dental care. With this information, you can make education more tailored and promote prevention.

Material and methods. A study was carried out among 15-year-old adolescents in Iceland the years 2014 and 2016. A quantitative research method was applied where printed questionnaires were submitted to adolescents in 10 grades 2014 and 2016. R and Rstudio was used for statistical analysis. Parameters were resident, gender and parent country of origin. Descriptive statistics were used for the results

Results. The response rate was $49 \%(n=4116), 51 \%(n=2092)$ boys and $49 \%(n=2023)$ girls. Majority, $67 \%(n=2759)$ lived in the capital area, 30\% ( $n=1238)$ by the seaside and 3\% ( $n=38)$ in the countryside. $86 \%(n=3521)$ had parents of Icelandic origin and $14 \%(n=593)$ one or both parents of other than Icelandic origin. There is a significant difference between boys and girls in tooth brushing, flossing and in using fluoride-mouthwash where the boys have worse oral hygiene habits than girls. $76.6 \%(n=446)$ of adolescents with parents of foreign origin see the dentist regularly compared to $91.3 \%(n=3185)$ of adolescents with Icelandic parents. In 2013 an agreement on full payment of dental expenses by IHI came into effect for children up to 18-years-old. 88.2\% $(n=2021)$ regularly went to see the dentist in 2014 compared to 90.3\% ( $n=1626)$ in 2016.

Discussion. The investigation covered the whole country and therefore contributes a valuable insight into some oral health lifestyles of 15-year old's in Iceland and is essential to target preventive measures for this age group. The results indicate that boys generally have poorer oral hygiene than girls and may need a tailor made preventive program more effective to them. There is no significant difference between parts of the country, which indicates that the country has become more homogenous as previous studies have shown.

Keywords: Oral Hygiene, Brushing, Dental Floss, Prevention

Correspondence: Dana Rún Heimisdóttir, e-mail: danaheimis@gmail.com 